\title{
The Effect of Brainstorming on Loneliness Level among Elderly
}

\section{Elyas Arif Budiman ${ }^{1 *}$, Zidni Nuris Yuhbaba², Guruh Wirasakti³, Wike Rosalini}

\author{
1,2Psychiatric Nursing,Faculty of Health Sciences, Universitas dr. Soebandi, Indonesia; \\ elyas@stikesdrsoebandi.ac.id (Corresponding Author) \\ 3Emergency Nursing, Faculty of Health Sciences, Universitas dr. Soebandi, Indonesia \\ ${ }^{4}$ Pediatric Nursing, Faculty of Health Sciences, Universitas dr. Soebandi, Indonesia
}

\begin{tabular}{|c|c|}
\hline Article Info: & ABSTRACT \\
\hline Submitted: & Loneliness is an unpleasant subjective experience for the elderly when several \\
\hline 09-09-2021 & important criteria in social relationships are hampered or not met. Loneliness in the \\
\hline Revised: & elderly can be overcome with positive social support. The purpose of the study was to \\
\hline $10-11-2021$ & determine the effect of social support with the brainstorming method on the level of \\
\hline Accepted: & loneliness in the elderly. This study uses a pre-experiment with a pre-test-post-test \\
\hline $18-11-2021$ & design approach. The population is elderly who live in elderly social services and have \\
\hline & certain characteristics, amounting to 66 people. The sample amounted to 33 people \\
\hline & given 2 times for 2 weeks with a duration of 40 minutes. The data collection method \\
\hline DOI: & used the R-UCLA Loneliness Scale and then the data were analyzed using the \\
\hline https://doi.org/10.53713/nhs.v1i3.75 & Wilcoxon Signed Rank Test statistical test with the results of $p$ value $=0.000<a=$ \\
\hline & $\begin{array}{l}0.05 \text {. The conclusion in this study that social support with the brainstorming method } \\
\text { has an influence on the level of loneliness because in the brainstorming process the }\end{array}$ \\
\hline & elderly are able to improve interpersonal communication and create a harmonious \\
\hline (c) $\underset{\text { BY }}{\text { SA }}$ () & loneliness in the elderly. \\
\hline
\end{tabular}

This work is licensed

under CC BY-SA License.

Keywords: brainstorming; elderly; loneliness; social support

\section{INTRODUCTION}

The increasing proportion of the elderly (elderly) population requires special attention and treatment in the implementation of development. Age 60 years and over is the final stage of the aging process which has an impact on three aspects, namely biological, economics, and social. Biologically, the elderly will experience a continuous aging process characterized by decreased physical endurance and vulnerability to disease. Economically, the elderly are generally seen as a burden rather than a resource. Socially, the life of the elderly is often perceived negatively, or does not provide much benefit to the family and society (Statistik Penduduk Lanjut Usia, 2015)

The number of elderly people in Indonesia reached 20.24 million, equivalent to $8.03 \%$ of the entire population of Indonesia in 2014. The number of elderly women is greater than that of men, namely 10.77 million elderly women compared to 9.47 million elderly men. male. The number of elderly people in East Java is around $10.40 \%$, while the percentage of neglected elderly men is $6.44 \%$ and the percentage of neglected elderly women is 7.86 (Statistik Penduduk Lanjut Usia, 2015). With the increasing number of elderly people, the loneliness rate is even greater, it is estimated that $50 \%$ of the elderly are now suffering from loneliness

The prevalence of loneliness in the elderly according to research conducted in (Ardianto, 2015) shows the results that most of the elderly are in a state of moderate loneliness which is $66.67 \%$ followed by mild loneliness by $23.33 \%$ and the remaining $10 \%$ is included in the high loneliness category. Loneliness experienced by the elderly must get attention from the surrounding community. The elderly need to be given activities that involve physical, psychological and social relationships that aim to eliminate loneliness, or at least it can be reduced (Arslantaş et al., 2015)

Loneliness itself is a mental and emotional state which is mainly characterized by feelings of alienation and a lack of meaningful relationships with others (Amalia, 2013). When experiencing loneliness, individuals will feel dissatisfied (not satisfied), deprivied (lost), and distressed (suffering). This does not mean that loneliness is the same all the time. Different individuals may have different feelings of loneliness in different situations (Russell et al., 1978).

Loneliness is a very dominant symptom in the elderly (Beyene et al., 2002). These fear states have varying degrees, typically influenced by the degree and quality of social support. This is of course reinforced by various opinions 
which suggest that loneliness is directly related to limited social support (Liu et al., 2016). Social support is a predictor of the emergence of loneliness. This means that individuals who have limited social support are more likely to experience loneliness, while individuals who have better social support are less lonely (Li, XinLi, 2019). This also shows the importance of social support behind the elderly to anticipate the problem of (Amalia, 2013)

Social support is comfort, attention, and rewards that are relied on when individuals experience difficulties (Liu et al., 2016). Various social support programs have been pursued by the social service to deal with the problem of loneliness in the elderly in elderly social services. Starting from recreational activities to tourist attractions, joint gymnastics activities, spiritual activities, marriage programs for the elderly, and providing television and radio facilities (Donovan \& Blazer, 2020). However, the social support program that has been pursued by the local social service still has not been able to overcome the problem of loneliness in the elderly so that researchers innovate to provide social support with the brainstorming method where this method is used as a form of social support in accordance with (Orford, 1992) theory, namely social support in the form of social integration. which refers to the individual's feeling as a part of a group or society (sense of belongingness).

Brainstorming is a group creativity technique that is carried out to find conclusions for a particular problem by collecting a list of spontaneous ideas contributed by its members (Szanton et al., 2014). The results of the (Wreksoatmodjo, 2016) show that cognitive activity (brainstorming) affects cognition in the elderly. From the results of this study, brainstorming activities can be applied to the elderly as one of the activities that are expected to eliminate the feeling of loneliness in the elderly group living in orphanages.

Based on the study, it can be explained that brainstorming can reduce loneliness that occurs in the elderly. Moving on from the theories and phenomena above, the researchers are interested in seeing how big the effect of brainstorming activities on the level of loneliness in the elderly.

\section{METHOD}

The type of research used in this study was pre-experimental with the research design using a pre-test-post-test design by observing 2 times. This research was conducted in Bondowoso elderly social services with a population of 66 elderly. The sample in the study amounted to 33 elderly. The sampling technique used in this study was purposive sampling.

The action given to the elderly in reducing the level of loneliness is social support that will be given to the elderly in the form of emotional support and social integration using the brainstorming method. for 30-40 minutes. Given 2 times during the study. Social support will be measured by the extent to which the elderly received the social support obtained during the orphanage.

The measuring instrument used to measure loneliness is the loneliness variable data collection method using the Loneliness Scale used is the scale compiled by (Russell et al., 1978) namely Revised University of California, Los Angeles Loneliness Scale (R-UCLA Loneliness Scale) which has been translated into in Indonesian by the researcher with the results The validity index of this questionnaire is $0.320-0.658$ and the reliability value is 0.883 .

The data that has been obtained from the measurement results will be processed computationally well with the statistical package for the social sciences (SPSS) program. The data is then analyzed through the Wilcoxon SignedRank Test calculation., ordinal minimum measurement level.

\section{RESULT}

Information on descriptive statistics of research results based on the characteristics of respondents in detail can be seen in the following table.

Table 1. Description of Respondents Characteristics by Age

\begin{tabular}{cccc}
\hline No & Characteristics of Respondents & Frequency & Percentage \\
\hline 1 & $60-69$ & 12 & $36.4 \%$ \\
\hline 2 & $70-79$ & 13 & $39.4 \%$ \\
\hline 3 & $>80$ & 8 & $24.2 \%$ \\
\hline & Total & 33 & $100.0 \%$
\end{tabular}

Based on the results of the table above shows that the characteristics of respondents based on age at most are ages with a range of $70-79$ years at $39.4 \%$. 
Table 2. Description of Respondents' Characteristics by Gender

\begin{tabular}{clcc}
\hline No & Characteristics of Respondents & Frequency & Percentage \\
\hline 1 & Man & 21 & $63.6 \%$ \\
\hline 2 & Women & 12 & $36.4 \%$ \\
\hline & Total & 33 & $100.0 \%$ \\
\hline
\end{tabular}

Based on the results of the table above, it shows that the characteristics of respondents based on gender in this study are mostly male, which is $63.6 \%$.

Table 3. Description of Respondents Characteristics by Status

\begin{tabular}{|c|c|c|c|}
\hline No & Characteristics of Respondents & Frequency & Percentage \\
\hline 1 & Widower & 19 & $57.6 \%$ \\
\hline 2 & Widow & 9 & $27.3 \%$ \\
\hline \multirow[t]{2}{*}{3} & Married & 5 & $15.2 \%$ \\
\hline & Total & 33 & $100.0 \%$ \\
\hline
\end{tabular}

Based on the results of the table above, it shows that the characteristics of respondents based on their marriage status are widowers of $57.6 \%$ and widows of $27.3 \%$.

Table 4. Description of Frequency and Percentage of Social Support Family

\begin{tabular}{crcc}
\hline No & Social support level & Frequency & Percentage \\
\hline 1 & Never & 29 & $87.9 \%$ \\
\hline 2 & Rarely & 4 & $12.1 \%$ \\
\hline \multicolumn{2}{r}{ Total } & 33 & $100.0 \%$ \\
\hline
\end{tabular}

Based on the table above, information is obtained that 33 respondents never received social support from their families as many as 29 elderly (87.9\%) and rarely as many as 4 elderly (12.1\%).

Information on the statistical results of differences in the level of loneliness in the elderly pretest posttest in detail can be seen in the following table.

Table 5. Description of the results of the Loneliness Level Pretest in the Elderly

\begin{tabular}{clcc}
\hline No & \multicolumn{1}{c}{ Loneliness Level } & Frequency & Percentage \\
\hline 1 & Not Lonely & 2 & $6.1 \%$ \\
\hline 2 & Low Loneliness & 11 & $33.3 \%$ \\
\hline 3 & Moderate Loneliness & 20 & $60.6 \%$ \\
\hline & Total & 33 & $100 \%$ \\
\hline
\end{tabular}

Based on the results of the study, the level of loneliness in the elderly during the pretest showed that the most elderly experienced moderate loneliness at $60.6 \%$.

Table 6 Description of the results of the Loneliness Level Post-test in the Elderly

\begin{tabular}{clccc}
\hline No & & Loneliness Level & Frequency & Percentage \\
\hline 1 & Not Lonely & 25 & $75.8 \%$ \\
\hline 2 & Low Loneliness & 8 & $24.2 \%$ \\
\hline 3 & Moderate Loneliness & 0 & $0.0 \%$ \\
\hline & Total & 33 & $100 \%$ \\
\hline
\end{tabular}

Based on the results of the study the level of loneliness in the elderly during the posttest showed that the elderly did not experience moderate loneliness at $75.8 \%$. 
Based on the results of the Wilcoxon signed rank test, the $Z$ value obtained is $-4.939 \mathrm{~b}$ with a $p$ value (Asymp. Sig.2-tailed) 0.000 . Therefore, in the experimental group there is an effect of social support with the brainstorming method on the level of loneliness in the elderly with a p value $0.000<$ alpha 0.005 .

\section{DISCUSSION}

Loneliness is an unpleasant subjective experience in which the quality and quantity of a person's social relationships has decreased significantly (Ong et al., 2016). Loneliness experienced by the elderly who live in social institutions is defined as a stressful subjective state experienced by the elderly as a reaction to dissatisfaction with the relationship that the elderly expect with the actual real situation (Beyene et al., 2002). Many elderly people feel left out, no longer needed, their unwillingness to accept new realities such as an illness that does not go away, the death of a spouse, is a small part of the overall unpleasant feelings that the elderly must face (Ardianto, 2015).

Loneliness experienced by the elderly in social services is not only caused by dissatisfaction with their current life, but also because the social support factor they receive is still low (Liu et al., 2016). Social support is a predictor for the emergence of loneliness, where the elderly who receive limited social support are more likely to experience loneliness (Pontinen \& Swails, 2017).

The results showed that before getting treatment the elderly experienced moderate loneliness and low loneliness, then after being given social support with the brainstorming method the level of loneliness in the elderly decreased and most of the elderly did not experience loneliness. The brainstorming method is a form of social support given to the elderly who experience loneliness with this method, it is hoped that this method can be used by the elderly as an educational game and can fill spare time when the elderly felt lonely. This method is used in terms of the form of social support in accordance with (Orford, 1992) theory, namely support in the form of social integration which refers to individual feelings as a part of a group or community (sense of belongingness).

Social support may come from various parties, but social support that is very meaningful in relation to the problem of loneliness is social support that comes from those who have emotional closeness such as family members or close friends (Chen et al., 2019). In this study, the activity provided by the researcher was a brainstorming activity that involved elderly colleagues at the social institution and the elderly felt entertained and enjoyed the activity because this activity involved colleagues at the orphanage, so this activity strengthens emotional bonds in the elderly (Fakoya et al., .

The purpose of brainstorming activities in this study is to facilitate the elderly in social needs such as socializing with all people who are in social institutions, so that they have many friends who can be invited to communicate, share experiences, and provide direction for a good life (Fakoya et al., 2020). These needs are needed by the elderly so that they can live prosperously at the end of their life. These needs are in line with Abraham Maslow's opinion, namely the need for security, social needs, self-esteem needs and self-actualization needs (Padila, 2013).

Elderly who get high social support have a strong feeling that the elderly is loved and appreciated. Elderly with high social support feel that other people care and need the elderly, this can eliminate the feeling of loneliness that occurs in the elderly, this is in accordance with the theory of Fessman and Laster (2000) which explains that the elderly who receive support better social life will not be too lonely (Liu et al., 2016).

The social support received by the elderly is able to change a person's response to previously received stressors (loneliness) (Sviarkaltsava, 2014). Individuals with high levels of social support have a strong feeling that the individual is loved and valued. Individuals with high social support feel that others care and need the individual, so that it can lead the individual to a prosperous state (Orford, 1992) In this study it was proven that the elderly who received social support with the brainstorming method had a significantly decreased level of loneliness, this was inversely proportional to the elderly who did not receive social support where the level of loneliness tended to remain.

Life satisfaction for the elderly will be achieved when they get general psychological well-being, namely opinion, health, a healthy lifestyle, as well as a good network of family and friends (Hacihasanoĝlu et al., 2012).Giving activity therapy that involves groups such as brainstorming can train the elderly to improve interpersonal relationships between group members, communicate, pay attention to each other, respond to others, express ideas, and receive external stimuli from the environment. The elderly in nursing homes spend more time with other elderly people to talk to each other about the problems they are experiencing (Nuraini et al., 2021). In this study, it is hoped that brainstorming activities can be used as a means for the elderly to obtain welfare through entertaining activities so that the problems of loneliness experienced by the elderly can be resolved and lead the elderly to a peaceful life at the end of their lives. 


\section{CONCLUSION}

The conclusion in this study that social support is the help or support that individuals receive from certain people in their lives. It is hoped that with social support, a person will feel cared for, appreciated and loved. By providing meaningful social support, the elderly who live in the service no longer experience loneliness and lead the elderly to a prosperous life.

\section{ACKNOWLEDGEMENT}

Thank you to the Faculty of Health Sciences, Universitas dr. Soebandi, who has provided support for research and also to the research place which provided extraordinary facilities for this research.

\section{REFERENCES}

Amalia, A. D. (2013). Kesepian dan Isolasi yang dialami Lansia. Jurnal Informasi, 18(02), 203-210.

Ardianto, H. D. (2015). Hubungan tingkat kesepian dengan kejadian insomnia pada lansia di pstw yogya unit budiluhur kasongan bantul. 1-10. http://digilib.unisayogya.ac.id/73/1/NASKAH PUBLIKASI.pdf

Arslantaş, H., Adana, F., Abacigil Ergin, F., Kayar, D., \& Acar, G. (2015). Loneliness in elderly people, associated factors and its correlation with quality of life: A field study from Western Turkey. Iranian Journal of Public Health, 44(1), 43-50.

Beyene, Y., Becker, G. A. Y., \& Mayen, N. (2002). Percetion of aging and sense of well-being among Latino elderly. Journal of Cross-Cultural Gerontology, 17(2), 155-172. https://doi.org/10.1023/A:1015886816483

Chen, L., Alston, M., \& Guo, W. (2019). The influence of social support on loneliness and depression among older elderly people in China: Coping styles as mediators. Journal of Community Psychology, 47(5), 1235-1245. https://doi.org/10.1002/jcop.22185

Donovan, N. J., \& Blazer, D. (2020). Social Isolation and Loneliness in Older Adults: Review and Commentary of a National Academies Report. American Journal of Geriatric Psychiatry, 28(12), 1233-1244. https://doi.org/10.1016/j.jagp.2020.08.005

Fakoya, O. A., McCorry, N. K., \& Donnelly, M. (2020). Loneliness and social isolation interventions for older adults: A scoping review of reviews. BMC Public Health, 20(1), 1-14. https://doi.org/10.1186/s12889-020-8251-6

Hacihasanoĝlu, R., Yildirim, A., \& Karakurt, P. (2012). Loneliness in elderly individuals, level of dependence in activities of daily living (ADL) and influential factors. Archives of Gerontology and Geriatrics, 54(1), 61-66. https://doi.org/10.1016/j.archger.2011.03.011

Li, XinLi, X. (2019) "Illness uncertainty, social support, and coping mode in hospitalized patients with systemic lupus erythematosus in a hospital in Shaanxi, China", PLoS ONE, 14(2), pp. 1-11. doi: 10. 1371/journal. pone. 0211313., He, L., Wang, J., \& Wang, M. (2019). Illness uncertainty, social support, and coping mode in hospitalized patients with systemic lupus erythematosus in a hospital in Shaanxi, China. PLOS ONE, 14(2), 1-11. https://doi.org/10.1371/journal.pone.0211313

Liu, L., Gou, Z., \& Zuo, J. (2016). Social support mediates loneliness and depression in elderly people. Journal of Health Psychology, 21(5), 750-758. https://doi.org/10.1177/1359105314536941

Nuraini, B. A., Susumaningrum, L. A., Susanto, T., Rasni, H., \& Kurdi, F. (2021). The Description of Elderly Social Interaction during COVID-19 Pandemic in Nursing Home of Jember. 1(2), 100-106.

Ong, A. D., Uchino, B. N., \& Wethington, E. (2016). Loneliness and Health in Older Adults: A Mini-Review and Synthesis. Gerontology, 62(4), 443-449. https://doi.org/10.1159/000441651

Orford, J. (1992). Community Psychology Theory and Practice. 83, 82-83.

Padila. (2013). Buku Ajar Keperawatan Gerontik. Nuha Medika.

Pontinen, H. M., \& Swails, J. A. (2017). UCLA Loneliness Scale. Encyclopedia of Personality and Individual Differences, 1-3. https://doi.org/10.1007/978-3-319-28099-8_95-1

Russell, D., Peplau, L. A., \& Ferguson, M. L. (1978). Developing a Measure of Loneliness. Journal of Personality Assessment, 42(3), 290-294. https://doi.org/10.1207/s15327752jpa4203_11

Statistik Penduduk Lanjut Usia. (2015). Badan Pusat Statistik.

Sviarkaltsava, V. (2014). The Effect of Loneliness on the Perception and Learning of Negative Words. 2014, 51-67.

Szanton, S. L., Roth, J., Nkimbeng, M., Savage, J., \& Klimmek, R. (2014). Improving unsafe environments to support aging independence with limited resources. Nursing Clinics of North America, 49(2), 133-145. https://doi.org/10.1016/j.cnur.2014.02.002

Wreksoatmodjo, B. R. (2016). Pengaruh Aktivitas Fisik terhadap Fungsi Kognitif Lanjut Usia di Jakarta. Cdfk, 43(1), 7-12. 